\title{
Response of Some Sugar Beet Varieties Grown under Different Saline Soils and Plant Populations
}

\author{
Sadek, K.A., B.S.I. Makhlouf, A.M.E. Fadel and Amira E. El-Sherief \\ Agron., Res. Dept., Sugar Crops Res. Inst., Agric. Res. Center, Giza, Egypt (ARC)
}

\begin{abstract}
Two field experiments were conducted in Senouris; Tamya Res. Station, Fayoum Governorate, Egypt (latitude of $30.82^{\circ} \mathrm{N}$ and longitude of $29.40^{\circ} \mathrm{E}$ ) during the two successive seasons of $2017 / 2018$ and $2018 / 2019$, to evaluate the performance of three sugar beet varieties (Alauda, Nefirtitis and Carnuta), sown using three spaces between hills (15, 20 and $25 \mathrm{~cm}$ ) under conditions of loamy (saline soil) and silt-clay soils, in two separate field experiments on yield and quality. Under each soil condition; the experimental design was a split-plot with three replications. Collected data were analyzed combined over the two locations in each season. Hill spaces were allocated in the main plots, whereas, varieties were randomly distributed in the sub-plots.

Results showed a positive statistical response in root length and diameter, as well as, root fresh weight/plant, root and sugar yields/fad, when sugar beet plants were sown under silt-clay soil, compared to saline soil (loamy texture) conditions. Meanwhile, the highest $\mathrm{K}$ and $\mathrm{Na}$ contents and sucrose\% were obtained under saline soil conditions, in both seasons. Root dimensions, root fresh weight/plant, root and sugar yields/fad positively and continuously responded to increasing hill spaces up to $25 \mathrm{~cm}$. However, the insignificant differences among sowing hills were found in $\mathrm{K}$, $\mathrm{Na}$ and alpha-amino $\mathrm{N}$ contents, sucrose $\%$ and purity $\%$, in both seasons. The examined varieties differed significantly in root diameter and root fresh weight/plant, in both seasons, as well as, root length only in the $1^{\text {st }}$ season, and root yield/fad in the $2^{\text {nd }}$ one. The heaviest roots were obtained from Carnuta variety and superiority over the other tested varieties. The significant differences among sugar beet varieties in sugar yield/fad were showed only in the $2^{\text {nd }}$ season, meantime, the differences among varieties were insignificant in $\mathrm{K}, \mathrm{Na}$, alpha-amino $\mathrm{N}$ contents, sucrose $\%$ and purity\%, in both seasons. The highest sugar yield/fad was obtained from Carnuta variety, followed by Alauda, while the least sugar yield/fad resulted from Nefirtitis variety, in the $2^{\text {nd }}$ season.

The interaction between soil types and hill spaces showed significant effects on root diameter in both seasons and sugar yield/fad only in the $2^{\text {nd }}$ season. Carnuta variety recorded the highest. Significant values of root length under siltclay soil conditions, in the $1^{\text {st }}$ season. The significant interaction between hill spaces and varieties was reflected in purity\% in the $2^{\text {nd }}$ season. Alauda achieved the highest purity $\%$ at 15 and $25 \mathrm{~cm}$ between hills, meantime, Nefirtitis gave the best purity $\%$ at $20 \mathrm{~cm}$ between hills. The $2^{\text {nd }}$ order interaction, among the three factors under study had a significant influence on sucrose $\%$ only in the $2^{\text {nd }}$ season. The highest sucrose $\%$ was attained from the interaction between varieties and distances between hills under saline soil (loamy texture) than silt-clay soil conditions.

Based upon the obtained results, it was found that sowing Carnuta variety at $25 \mathrm{~cm}$ between hills might be recommended to achieved the highest root and sugar yields/fad under silt-clay and/or saline soil (loamy texture) conditions.
\end{abstract}

Key words: Sugar beet, saline soil, plant population, varieties, yield, quality.

INTRODUCTION

Sugar beet (Beta vulgaris, L.) is the second largest crop for sugar production in the world after sugar cane. It is generally better adapted to less favorable ecological conditions than sugar cane (EL-Refaey et al., 2012). Soil salinity is a major environmental stress that affects agricultural production worldwide. Salinity of soil is a major abiotic stress that has adverse effects on physiological and metabolic processes of plants leading to decreased growth and yield (Azizpour et al., 2010 and Merwad, 2015). Although sugar beet is salt-tolerant compared to other crops, it is sensitive to salinity at the germination and early seedling stages (Maas, 1986, Kaffka and Hembree, 2004 and Sadughi et al., 2015). Sugar beet is cultivated under a wide range of climatic conditions and is considered one of the most salt tolerant crops (Tognetti et al. 2003) with a threshold electrical conductivity (EC) (the maximum soil salinity that does not reduce the crop yield) of $7.0 \mathrm{dS} \mathrm{m}^{-1}$ (Marschner 1995). Germination and root length were significantly affected by salt composition, cultivars and salinity levels (Asghar et al., 2007). Yan et al., (2014) showed that, seedling emergence in variety Tianyan309 was much lower than that in variety KWS3418 in the initial six-day. Low salinity $(86 \mathrm{mM} \mathrm{NaCl})$ had insignificant effect on shoot and root dry weights, while 171 and $257 \mathrm{mM} \mathrm{NaCl}$, inhibited shoot and root dry weights of the two cultivars. Feizi et al., (2017) indicated that, the white sugar yield decreased by increasing the water salinity. Salts leaching significantly increased the root yield, white sugar yield and white sugar concentration. With higher levels of water salinity molasses sugar, leaf weight and the concentrations of $\mathrm{Na}, \mathrm{K}$, and $\alpha$ - amino- $\mathrm{N}$ in sugar beet significantly increased. Abbas and Al-Jbawi (2019), showed that, leaf area, leaf number, total dry matter and net assimilation rate were decreased under salinity stress conditions compared to the control.

Plant density/unit area of cultivated land is a major factor in determining the quality and quantity of the sugar roots, for instance, optimum plant 
density provides a larger area of nutrients which allows plant sufficient quantity of water, light and thus raises the efficiency of photosynthesis which contribute to increase the dry matter proportion in the roots and higher roots yield per unit area (Freckleton et al., 1999). The optimum plant densities in sugar beet is very necessary to have high root yield with good quality. Sugar beet intensification to the optimum density results in mature plants that are sufficiently crowded to efficiently use resources such as water, nutrients, and sunlight, without high mortality rate (Heitholt and Sassenrath, 2010). The lower plant populations and presence of many missed hills in the field reduced the quality mainly of sugar content and white sugar yield as a result of increased impurities content (Minx, 1993 and Lauer, 1995). Ismail and Allam (2007), showed that, plant densities significantly affected root length and diameter, fresh weight/plants, as well as sodium $\%$ and sucrose $\%$ in both seasons in addition to sugar yield in the $2^{\text {nd }}$ one. They added that, sowing sugar beet at 28000 and 42000 plants/fad. gave the highest yields of root and sugar and quality traits. Nafei et al., (2010), cleared that, increasing plant densities from 28000 to 42000 significantly increased root length, diameter, fresh weight/plants, sucrose $\%$, total soluble solids, as well as, top, root and sugar yields/fad). Shalaby et al. (2011) found that, increasing plant spacing from 15 to $25 \mathrm{~cm}$ increased significantly root length and diameter, fresh weight, sucrose \%, root and sugar yields. Impurities\%, i.e.; $\mathrm{N}, \mathrm{Na}$ and $\mathrm{K}$, were decreased significantly in both seasons. Safina et al. (2012) demonstrated that increasing plant density from 22400 to 44800 though 37333 plants/fad significantly increased root fresh weight in the first season. Increasing plant density from 22400 to 37333 significantly increased top yield and T.S.S in both seasons. Increasing plant density from 37333 to 44800 plants fad significantly increased sucrose content by $3.4 \%$ in the $2^{\text {nd }}$ season and purity by $3.7 \%$ and $1.4 \%$ in the $1^{\text {st }}$ and $2^{\text {nd }}$ seasons, respectively. Hozayn et al. (2013) showed that, growing sugar beet at 36000 plants/fad increased sucrose and purity percentages, top, root and sugar yields, as compared to the other plant densities (i.e.; 16, 24, 32 and 40 thousands/fad).

All sugar beet genotypes cultivated in Egypt are imported from other countries, so, it is preferable to evaluate it under local conditions. In Egypt, sugar beet can be cultivated without competition to other crops, because of its tolerance to salinity and its ability to produce high yields under saline soil conditions. Variety is the corner stone for production process. Aly (2006), El-Bakary (2006) and Ismail et al. (2006) found that genotypes differed significantly in root length, diameter and fresh weight, impurities, sucrose and purity percentages, as well as, top, root and sugar yields/fad, in both seasons. Abd El-Aal et al., (2010), revealed a significant variation in yield productivity and root quality among sugar beet varieties. Kawemira and Gloria varieties gave the highest sugar yield followed by Nejma. Meanwhile, Lola exhibited the least sugar yield. Safina et al., (2012) cleared that sugar beet cultivars significantly differed in productivity and quality. Hozayn et al., (2013) recorded significant differences among the tested cultivars in all studied characters of sugar beet. Ahmed et al., (2017) showed that, sugar beet varieties differed significantly in root length, root and sugar yields/fad, as well as, sucrose, purity and impurities percentages. Thalooth et al., (2019) found that, Heba variety recorded the highest values of root length, diameter and fresh weight/plant, as well as, root, top and sugar yields/fad, while Sirana variety was ranked the second.

This work was conducted to evaluate the performance of three sugar beet varieties under different plants spacing in clay saline soil conditions.

\section{MATERIALS AND METHODS}

Two field experiments were conducted in Senouris; Tamya Res. Station, Fayoum Governorate, Egypt, (latitude of $30.82^{\circ} \mathrm{N}$ and longitude of $29.40^{\circ} \mathrm{E}$ ). The study continued for two successive seasons (2017/2018 and 2018/2019). The mean objectives were evaluate the performance of three sugar beet (Bete vulgaris var saccharifeu) varieties (Alauda, Nefirtitis and Carnuta), under three hill spacing $(15,20$ and $25 \mathrm{~cm})$. Two separate field experiments were conducted in loamy (saline soil) and silt-clay soils, characters of growth, yield and quality were evaluated. Under each soil condition, the experimental design was a split plot with three replications: Hill spacing were allocated in the main plots, whereas, varieties were randomly distributed in the sub-plots. The sub plot area was $21 \mathrm{~m}^{2}$ including 6 ridges of $0.50 \mathrm{~m}$ in width and $7 \mathrm{~m}$ in length. The preceding crop was clover, in both seasons. Nitrogen fertilizer was applied at $80 \mathrm{~kg}$ $\mathrm{N} /$ fad as urea $(46.5 \% \mathrm{~N})$ in two equal doses, after thinning and one month later. Phosphorus fertilizer was applied in form of calcium superphosphate $\left(\begin{array}{llll}15 \% & \mathrm{P}_{2} \mathrm{O}_{5}\end{array}\right)$ at $30 \mathrm{~kg} \quad \mathrm{P}_{2} \mathrm{O}_{5} /$ fad. during seedbed preparation. Potassium fertilizer was added at $24 \mathrm{~kg}$ $\mathrm{K}_{2} \mathrm{O} /$ fad as potassium sulphate $\left(48 \% \mathrm{~K}_{2} \mathrm{O}\right)$ with the $2^{\text {nd }}$ nitrogen dose. Sugar beet was sown in the $2^{\text {nd }}$ week of September, while harvesting was done 7month later, in both seasons. The rest of agricultural practices were followed as recommended by Sugar Crops Research Institute.

Soil samples were taken at random from the experimental sites at a depth of 0-30 cm from soil surface. The analyses of silt-clay and loamy (saline 
soil) soils were according to Jackson (1967). presented in Tables 1 and 2, respectively.

\section{Recorded data:}

At harvest, ten plants were taken at random from guarded ridges in each sub plot to determine the following characteristics:

1. Root length $(\mathrm{cm})$.

2. Root diameter $(\mathrm{cm})$.

3. Root fresh weight (g/plant).

4. Impurities ( $\alpha$-amino $\mathrm{N}, \mathrm{Na}$ and $\mathrm{K}$ concentrations) of juice were estimated as (meq/100) g beet, according to Cooke and Scott (1993).

5. Sucrose percentage was estimated in fresh samples of sugar beet root using "Saccharometer" according to the method described by A.O.A.C. (2005).

6. Purity \% was calculated according to Cooke and Scott (1993).

The quality traits (impurities, sucrose $\%$ and purity\%) were determined in the Quality Control Laboratory at Fayoum Sugar Company, Egypt.

7. Root yield (ton/fad), plants were uprooted, topped, cleaned and weighed to estimate root yield (ton/fad).

8. Sugar yield was calculated according to the following equation:

Sugar yield (ton/fad) $=$ sucrose $\%$ x root yield (ton/fad)

\section{Statistical analysis:}

Data were statistically analyzed as shown by

Snedecor and Cochran (1981). Least significant difference (LSD) was used to compare the differences between treatment means at $5 \%$ level of probability (Waller and Duncan (1969)).

\section{RESULTS AND DISCUSSION}

Root length and diameter $(\mathrm{cm})$, root fresh weight (g/plant) and root yield (ton/fad):

Data in the Table 3 showed a positive statistical response in root length and diameter, as well as, root fresh weight/plant and root yield/fad, when sugar beet plants were sown under silt-clay soil conditions, compared to saline soil. Sowing sugar beet under saline soil (loamy) condition led to decreases in root length amounted to 17.40 and $19.46(\mathrm{~cm})$, root diameter 4.49 and $5.41(\mathrm{~cm})$, root fresh weight/plant 0.469 and $0.616(\mathrm{~kg})$ and root yield/fad 23.7 and 25.3 (tons), compared to sowing in silt-clay soil condition, in the $1^{\text {st }}$ and $2^{\text {nd }}$ seasons, respectively. The reduction in the root dimensions might be due to an increase of salts in the soil sector (Table 2), where the osmotic pressure increases in root growth area. Plant to resist those unsuitable conditions, raise the internal osmotic pressure of the cytoplasm, which leads to the loss of the bio-energy necessary for development and growth, which reflected negatively on the final root fresh weight/plant and root yield/fad.

The obtained results in the same table cleared that, root dimensions, root fresh weight/plant and root yield/fad positively and continuously responded to hill spaces, in both seasons, as the distance between hills was gradually increased, all previous characteristics, were gradually and significantly increased.

Table 1: Silt-clay soil physical and chemical properties of the experimental sites.

\begin{tabular}{|c|c|c|c|c|c|c|c|c|}
\hline \multirow[t]{2}{*}{ Seasons } & \multicolumn{3}{|c|}{ Particle size distribution } & \multicolumn{3}{|c|}{$\begin{array}{c}\text { Available nutrients } \\
\text { (mg/kg soil) }\end{array}$} & \multirow{2}{*}{$\begin{array}{c}\mathrm{EC} \\
(\mathrm{ds} / \mathrm{m})\end{array}$} & \multirow{2}{*}{$\underset{(1: 2.5)}{\text { pH }}$} \\
\hline & Sand\% & Silt \% & Clay \% & $\mathbf{N}$ & $\mathbf{P}$ & $\mathbf{K}$ & & \\
\hline $2017 / 18$ & 25.2 & 35.9 & 38.9 & 75.53 & 4.45 & 158.6 & 2.45 & 7.95 \\
\hline $2018 / 19$ & 24.4 & 36.2 & 39.4 & 74.25 & 4.59 & 149.8 & 2.55 & 7.71 \\
\hline \multirow{2}{*}{ Seasons } & \multicolumn{8}{|c|}{ Soluble cations and anions (meq/l) } \\
\hline & $\mathrm{Ca}^{++}$ & $\mathrm{Mg}^{++}$ & $\mathrm{Na}^{+}$ & $\mathrm{K}^{+}$ & $\mathrm{HCO}_{3}^{-}$ & $\mathrm{Cl}^{-}$ & \multicolumn{2}{|c|}{$\mathrm{SO}_{4}^{--}$} \\
\hline $2017 / 18$ & 4.79 & 4.45 & 17.45 & 0.35 & 0.86 & 19.59 & \multicolumn{2}{|c|}{5.45} \\
\hline $2018 / 19$ & 5.20 & 4.25 & 16.85 & 0.36 & 0.95 & 19.35 & \multicolumn{2}{|c|}{5.25} \\
\hline
\end{tabular}

Table 2: Saline soil (loamy texture) physical and chemical properties of the experimental sites.

\begin{tabular}{|c|c|c|c|c|c|c|c|c|}
\hline \multirow[t]{2}{*}{ Seasons } & \multicolumn{3}{|c|}{ Particle size distribution } & \multicolumn{3}{|c|}{$\begin{array}{c}\text { Available nutrients } \\
\text { (mg/kg soil) }\end{array}$} & \multirow{2}{*}{$\begin{array}{c}\text { EC } \\
(\mathrm{ds} / \mathrm{m})\end{array}$} & \multirow{2}{*}{$\underset{(1: 2.5)}{\text { pH }}$} \\
\hline & Sand \% & Silt\% & Clay \% & $\mathbf{N}$ & $\mathbf{P}$ & $\mathbf{K}$ & & \\
\hline $2017 / 18$ & 38.9 & 36.2 & 24.9 & 19.5 & 6.3 & 137.5 & 6.8 & 8.7 \\
\hline $2018 / 19$ & 39.1 & 35.8 & 25.1 & 19.0 & 6.7 & 136.0 & 6.9 & 8.9 \\
\hline \multirow{2}{*}{ Seasons } & \multicolumn{8}{|c|}{ Soluble cations and anions (meq/l) } \\
\hline & $\mathrm{Ca}^{++}$ & $\mathrm{Mg}^{++}$ & $\mathbf{N a}^{+}$ & $\mathbf{K}^{+}$ & $\mathrm{HCO}_{3}^{-}$ & $\mathrm{Cl}^{-}$ & \multicolumn{2}{|c|}{$\mathrm{SO}_{4}^{---}$} \\
\hline $2017 / 18$ & 20.5 & 18.3 & 27.5 & 2.2 & 6.9 & 38.5 & \multicolumn{2}{|c|}{23.3} \\
\hline 2018/19 & 22 & 17.3 & 27 & 2.6 & 6.7 & 42.2 & \multicolumn{2}{|c|}{21} \\
\hline
\end{tabular}


Table 3: Root length and diameter $(\mathrm{cm})$, root fresh weight (g/plant) and root yield (ton/fad) as affected by soil types, hill spacing and varieties in 2017/2018 and 2018/2019 seasons.

\begin{tabular}{|c|c|c|c|c|c|c|c|c|}
\hline \multirow{2}{*}{ Treatment } & \multicolumn{2}{|c|}{$\begin{array}{l}\text { Root length } \\
\text { (cm) }\end{array}$} & \multicolumn{2}{|c|}{$\begin{array}{c}\text { Root diameter } \\
(\mathbf{c m})\end{array}$} & \multicolumn{2}{|c|}{$\begin{array}{c}\text { Root fresh weight } \\
\text { (g/plant) }\end{array}$} & \multicolumn{2}{|c|}{$\begin{array}{c}\text { Root yield } \\
\text { (ton/fad) }\end{array}$} \\
\hline & $\begin{array}{c}1^{\text {st }} \\
\text { season }\end{array}$ & $\begin{array}{c}2^{\text {nd }} \\
\text { season }\end{array}$ & $\begin{array}{c}1^{\text {st }} \\
\text { season }\end{array}$ & $\begin{array}{c}2^{\text {nd }} \\
\text { season } \\
\end{array}$ & $\begin{array}{c}1^{\text {st }} \\
\text { season }\end{array}$ & $\begin{array}{c}2^{\text {nd }} \\
\text { season } \\
\end{array}$ & $\begin{array}{c}1^{\text {st }} \\
\text { season } \\
\end{array}$ & $\begin{array}{c}2^{\text {nd }} \\
\text { season } \\
\end{array}$ \\
\hline \multicolumn{9}{|c|}{ Soil types (S) } \\
\hline Soil a & 38.07 & 38.50 & 10.62 & 10.81 & 1093 & 1119 & 40.33 & 42.52 \\
\hline Soil b & 20.67 & 19.04 & 6.13 & 5.40 & 624 & 503 & 16.63 & 17.22 \\
\hline LSD $_{0.05}$ & 0.81 & 0.94 & 0.16 & 0.21 & 34 & 44 & 0.43 & 0.70 \\
\hline \multicolumn{9}{|c|}{ Hill spaces $(\mathrm{H})$} \\
\hline $15 \mathrm{~cm}$ & 27.00 & 25.83 & 7.24 & 6.91 & 720 & 678 & 26.17 & 26.22 \\
\hline $20 \mathrm{~cm}$ & 29.17 & 29.00 & 8.58 & 8.04 & 886 & 808 & 28.55 & 29.83 \\
\hline $25 \mathrm{~cm}$ & 31.94 & 31.78 & 9.30 & 9.36 & 969 & 947 & 30.72 & 33.56 \\
\hline $\operatorname{LSD}_{0.05}$ & 0.99 & 1.15 & 0.19 & 0.27 & 42 & 54 & 0.53 & 0.85 \\
\hline \multicolumn{9}{|c|}{ Varieties $(\mathrm{V})$} \\
\hline Alauda & 29.72 & 28.50 & 8.35 & 8.00 & 840 & 777 & 28.11 & 29.39 \\
\hline Nefirtitis & 28.67 & 28.72 & 8.06 & 7.86 & 836 & 780 & 28.17 & 29.00 \\
\hline Carnuta & 29.72 & 29.39 & 8.71 & 8.45 & 899 & 875 & 29.16 & 31.22 \\
\hline LSD $_{0.05}$ & 0.63 & NS & 2.91 & 0.33 & 32 & 53 & NS & 0.98 \\
\hline \multicolumn{9}{|l|}{ Interactions: } \\
\hline $\mathrm{S} \times \mathrm{H}$ & n.s. & n.s. & $*$ & $*$ & n.s. & n.s. & n.s. & n.s. \\
\hline $\mathrm{S} \times \mathrm{V}$ & $*$ & n.s. & n.s. & n.s. & n.s. & n.s. & n.s. & n.s. \\
\hline $\mathrm{HxV}$ & n.s. & n.s. & n.s. & n.s. & n.s. & n.s. & n.s. & n.s. \\
\hline $\mathrm{S} \times \mathrm{H} \times \mathrm{V}$ & n.s. & n.s. & n.s. & n.s. & n.s. & n.s. & n.s. & n.s. \\
\hline
\end{tabular}

*: significant,: not significant, soil a: silt-clay and soil b: saline (loamy texture).

The highest values of root yield were recorded with sowing hills on $25 \mathrm{~cm}$ apart, followed by $20 \mathrm{~cm}$, then $15 \mathrm{~cm}$ in last rank, in both seasons. Similar results were observed by Nafei et al. (2010) and Hozayn et al. (2013). Those increases might be due to the low competition among plants for growth resources. The pronounced effect of wider hill spacing (i.e root dimensions and fresh weight), explained wider by hill spacing heavier that gave individual root fresh weight and the root yield.

Concerning the behavior of sugar beet varieties, results pointed-out that the examined varieties differed significantly in root diameter and root fresh weight/plant in both seasons, as well as, root length only in the $1^{\text {st }}$ season and root yield/fad in the $2^{\text {nd }}$ one. These results were in harmony with those obtained by Ahmed et al. (2017). The heaviest roots were obtained from Carnuta variety with superiority over the other tested varieties. The highest mean values of root yield/fad (31.22 ton) were recorded by Carnuta variety, followed by Alauda (29.39 ton), whereas the least value (29.00 ton) was obtained from Nefirtitis variety, in the $2^{\text {nd }}$ season. The superiority of Carnuta variety might due to better root traits (Table 3). In addition, the differences among sugar beet varieties might be due to the variation in the gene make-up and their response to the environmental conditions.
Potassium, sodium and $\alpha$-amino $N$ contents, sucrose and purity percentages and sugar yield (ton/fad):

The most important factors which affect the quality of sugar beet roots are the percentage of potassium, sodium and alpha-amino $\mathrm{N}$ contents of root juice, as well as, sucrose percentage (Table 4). Results revealed that, the differences between soil types on potassium and sodium contents, sucrose $\%$ and sugar yield/fad were significant, in both seasons. Under saline soil (loamy texture) conditions, the highest values of potassium and sodium contents and sucrose $\%$ were recorded (similar trend with Feizi et al., 2017), These results were true in both growing seasons. The highest values of sugar yield/fad was achieved under siltclay soil. This was due to the highest yield of the roots. Results pointed out that planting sugar beet under silt-clay soil conditions led to an increases in sugar yield/fad reached $87.46 \%$ (3.07 ton) in the $1^{\text {st }}$ season and $92.79 \%$ (3.35 ton) in the $2^{\text {nd }}$ season, compared to saline soil conditions.

As shown in the same table, insignificant differences among hills spaces $(15,20$ and $25 \mathrm{~cm}$ ) were found for all studied characters, except, sugar yield. 
Table 4: Potassium, sodium and $\alpha$-amino $N$ contents, sucrose and purity percentages and sugar yield (ton/fad) as affected by soil types, hill spacing and varieties in 2017/2018 and 2018/2019 seasons.

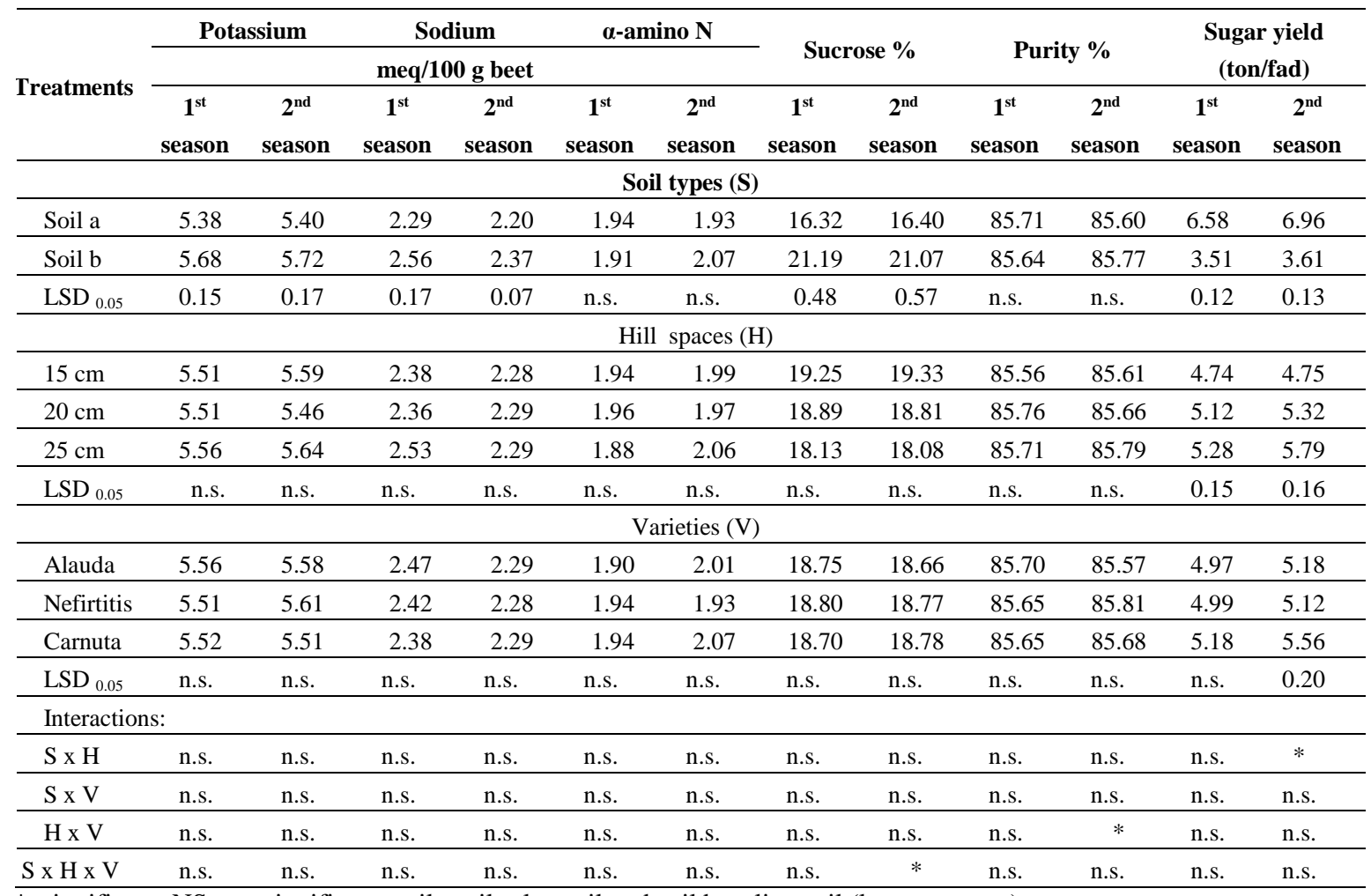

*: significant, NS: not significant, soil a: silt-clay soil and soil b: saline soil (loamy texture).

Increasing hill spaces to 20 and $25 \mathrm{~cm}$ led to a significant and gradually increments in sugar yield/fad amounted to 0.38 and 0.54 tons in the $1^{\text {st }}$ season, corresponding to 0.57 and 1.04 tons in the $2^{\text {nd }}$ one, as compared to sowing on $15 \mathrm{~cm}$ between hills. These results are in agreement with that reported by Shalaby et al. (2011) and Hozayn et al. (2013).

On the other hand, results given in Table (4) cleared that differences among sugar beet varieties in sugar yield/fad were significant only in the $2^{\text {nd }}$ season. Meantime, the other studied characters, were insignificant, in both seasons. The highest sugar yield/fad was obtained from Carnuta variety and surpassed other two varieties, followed by Alauda, while the least sugar yield/fad resulted from
Nefirtitis variety, in the $2^{\text {nd }}$ season. Carnuta variety achieved significant increases in sugar yield/fad amounted to $8.59 \%$ (0.44 ton) and $7.34 \%$ (0.38 ton), as compared to Nefirtitis and Alauda varieties, respectively, in the $2^{\text {nd }}$ season.

Effect of the interaction between soil types and hill spaces:

The interaction between soil types and hill spacing showed significant effects on root diameter in both seasons and sugar yield/fad only in $2^{\text {nd }}$ season, (Table 5). Increasing hill spaces from 15 to $25 \mathrm{~cm}$ led to a gradual and significant increases in root diameter in both seasons and sugar yield in the $2^{\text {nd }}$ season. This fact was true when sugar beet were sown under silt-clay and/or saline soil (loamy texture) conditions.

Table 5: The interaction between soil types and hill spaces on root diameter and sugar yield in 2017/2018 and/or 2018/2019 seasons.

\begin{tabular}{|c|c|c|c|c|}
\hline \multirow{2}{*}{ Soil types } & \multirow{2}{*}{ Hill spaces } & \multicolumn{2}{|c|}{ Root diameter $(\mathbf{c m})$} & \multirow{2}{*}{$\begin{array}{c}\text { Sugar yield (ton/fad) } \\
2^{\text {nd }} \text { season } \\
\end{array}$} \\
\hline & & $1^{\text {st }}$ season & $2^{\text {nd }}$ season & \\
\hline \multirow{3}{*}{ Soil a } & $15 \mathrm{~cm}$ & 9.22 & 9.19 & 6.65 \\
\hline & $20 \mathrm{~cm}$ & 10.92 & 10.97 & 6.97 \\
\hline & $25 \mathrm{~cm}$ & 11.71 & 12.27 & 7.27 \\
\hline \multirow{3}{*}{ Soil b } & $15 \mathrm{~cm}$ & 5.27 & 4.63 & 2.85 \\
\hline & $20 \mathrm{~cm}$ & 6.23 & 5.12 & 3.67 \\
\hline & $25 \mathrm{~cm}$ & 6.90 & 6.44 & 4.31 \\
\hline $\mathrm{LSD}_{0.05}$ & & 0.27 & 0.37 & 0.22 \\
\hline
\end{tabular}

Soil a: silt-clay soil and soil b: saline soil (loamy texture). 
The highest values of root diameter and sugar yield/fad were recorded with a distance of $25 \mathrm{~cm}$ between hills under silt-clay soil conditions. Results revealed that, planting sugar beet on $25 \mathrm{~cm}$ between hills under silt-clay soil conditions led to an increase in sugar yield/fad by $68.68 \%$ (2.96 ton) in the $2^{\text {nd }}$ season, compared to the same distance under saline soil.

Effect of the interaction between soil types and varieties

Data in Table (6) showed a significant interaction between soil types and varieties on root length only in 2017/2018 season. Carnuta variety recorded the highest significant values of root length under siltclay soil conditions; The superiority of Carnuta under silt-clay soil conditions might due to an increase in distance among sowing hills with suitable conditions for root growth. Results showed that Carnuta variety under silt-clay soil conditions led to increase root length/plant amounted to 1.11 and $1.34 \mathrm{~cm}$ compared to Alauda and Nefirtitis, respectively. On the other side, the same tested varieties recorded the lowest values of root length under saline soil (loamy texture) conditions.

Effect of the interaction between hill spaces and varieties:

The significant interaction between hill spacing and varieties on purity\% in 2018/2019 season was shown in Table (7). Sugar beet variety Alauda recorded the highest values of purity percentage when was sown on 15 and $25 \mathrm{~cm}$ between hills, meantime, Nefirtitis variety gave the best purity with sowing hills on $20 \mathrm{~cm}$. The superiority of Alauda and/or Nefirtitis varieties might due to increases in sucrose and decreases in impurities in root juice, in addition to, the different behavior of cultivars at different planting distances among hills. The Alauda variety recorded the least values with sowing hills on $20 \mathrm{~cm}$.

Effect of the interaction among soil types, hill spaces and varieties:

The $2^{\text {nd }}$ order interaction, among the three factors under study showed a significant influence on sucrose percentage only in 2018/2019 season as (Table 8). Nefirtitis variety achieved the highest sucrose percentage value when grown at $15 \mathrm{~cm}$ distances under saline soil conditions. While, the same variety did not achieve this superiority under silt-clay soils. In this regard, it could be noticed that, the tested sugar beet varieties at different hills distances gave the highest values of sucrose $\%$ under saline soil (loamy texture) than silt-clay soil conditions. This difference might due to the effect of salts concentration in soil solution that lead to an increase in osmotic pressure and therefore a reduction in water movement to plant and rate of absorption, which reflected positively on sugar accumulation in roots.

Table 6: Effect of the interaction between soil types and varieties on root length in $2017 / 2018$ season

\begin{tabular}{lcc}
\hline Soil types & Varieties & Root length $(\mathbf{c m})$ \\
\hline \multirow{3}{*}{ Soil a } & Alauda & 37.78 \\
\cline { 2 - 3 } & Nefirtitis & 37.55 \\
\cline { 2 - 3 } & Carnuta & 38.89 \\
\hline \multirow{2}{*}{ Soil b } & Alauda & 21.67 \\
\cline { 2 - 3 } & Nefirtitis & 19.78 \\
\hline LSD $_{0.05}$ & Carnuta & 20.56 \\
\hline
\end{tabular}

Soil a: silt-clay soil and soil b: saline soil (loamy texture).

Table 7: Effect of the interaction between hill spaces and varieties on purity in 2018/2019 season

\begin{tabular}{llc}
\hline Hill spaces & Varieties & Purity \% \\
\hline \multirow{3}{*}{$15 \mathrm{~cm}$} & Alauda & 85.93 \\
\cline { 2 - 3 } & Nefirtitis & 85.39 \\
\cline { 2 - 3 } $20 \mathrm{~cm}$ & Carnuta & 85.52 \\
\cline { 2 - 3 } & Alauda & 84.59 \\
\cline { 2 - 3 } & Nefirtitis & 86.23 \\
\cline { 2 - 3 } $25 \mathrm{~cm}$ & Carnuta & 86.17 \\
\cline { 2 - 3 } & Alauda & 86.20 \\
\hline LSD $_{0.05}$ & Nefirtitis & 85.82 \\
\cline { 2 - 3 } & Carnuta & 85.35 \\
\hline
\end{tabular}


Table 8: Effect of the interaction among soil types, hill spaces and varieties on sucrose in 2018/2019 season

\begin{tabular}{|c|c|c|c|c|}
\hline \multirow{3}{*}{ Soil types } & \multirow{3}{*}{ Hill spaces } & \multicolumn{3}{|c|}{ Sucrose \% } \\
\hline & & \multicolumn{3}{|c|}{ Varieties } \\
\hline & & Alauda & Nefirtitis & Carnuta \\
\hline \multirow{3}{*}{ Soil a } & $15 \mathrm{~cm}$ & 17.17 & 16.77 & 16.83 \\
\hline & $20 \mathrm{~cm}$ & 16.37 & 16.20 & 16.80 \\
\hline & $25 \mathrm{~cm}$ & 15.60 & 15.97 & 15.93 \\
\hline \multirow{3}{*}{ Soil b } & $15 \mathrm{~cm}$ & 21.03 & 22.23 & 21.97 \\
\hline & $20 \mathrm{~cm}$ & 21.50 & 21.17 & 20.80 \\
\hline & $25 \mathrm{~cm}$ & 20.30 & 20.30 & 20.37 \\
\hline $\operatorname{LSD}_{0.05}$ & & & 0.82 & \\
\hline
\end{tabular}

Soil a: silt-clay soil and soil b: saline soil (loamy texture)

\section{CONCLUSION}

Under conditions of the present work, it was found that sowing Carnuta variety of sugar beet at $25 \mathrm{~cm}$ among hills might recommended to achieve the highest root and sugar yields/fad, under silt-clay and/or saline (loamy texture) soil conditions.

\section{REFERENCES}

A.O.A.C. (2005). Association of Official Analytical Chemists. Official methods of analysis, $26^{\text {th }} \mathrm{Ed}$. A.O.A.C., International, Washington, D.C; USA.

Abbas, F. and E. Al-Jbawi .(2019). Effect of salinity and potassium enrichment on some growth attributes in sugar beet (Beta vulgaris, L.). J. Agric. Sci. and Tech. B to . 9: 152-159.

Abd El-Aal, A. M., A.I. Nafie and Abdel Aziz, Ranya M. (2010). Response of some sugar beet genotypes to nitrogen fertilization under newly reclaimed land conditions. Egypt. J.Appl. Sci.25(6B) 194-208.

Ahmed, A.Z. and A.O. Awadalla and Sakina, R. Abazid (2017). Possibility of sugar beet production in Toshka region. I Assessment of the optimum harvesting age. J. Plant Production, Mansoura Univ., 8 (12): 1409 - 1415.

Aly, E.F. (2006). Effect of environmental conditions on productivity and quality of some sugar beet varieties. Ph. D. Dissertation. Fac. of Agric.Benha Univ.Egypt.

Asghar, A., J. afarzadeh and N. Aliasgharzad. (2007). Salinity and salt composition effects on seed germination and root length of four sugar beet cultivars. Biologia Bratislava, 62(5); 562564.

Azizpour, K., M.R. Shakiba, K.S.N. Khosh, H. Alyari, M. Moghaddam, E. Esfandiari and M. Pessarakli .(2010). Physiological response of spring durum wheat genotypes to salinity. J. Plant Nut. 33: 859-873.

Cooke, D.A. and R.K. Scott (1993). The Sugar Beet Crop. Science Practice. Puplished by Chapman and Hall, London. P.,595-605.
El-Bakary, H.M.Y. (2006). Studies on yield and quality characters of some sugar beet varieties. .MSc. Thesis Fac. of Agric Al-Azhar Univ. Egypt.

EL-Refaey, R. A., E.H. El-Seidy, I.H. EL-Geddawy and H.M. EL-Sayed.(2012). Phenotypic and genotypic stability for some sugar beet genotypes. In Proc.of the $13^{\text {th }}$ Int. Conf. Agron., Fac. Agic., Benha Univ., Egypt, September 9-10, 317-331.

Feizi, M., J. Fallahzade and P. Noorshargh .(2017). Sugar beet yield response to different levels of saline irrigation water and leaching in an arid region. J. Plant Nutrition. ISSN: 0190-4167 (Print) 1532-4087. (Online) Journal homepage.DOI: 10.1080/01904167.2017.1415353.

Freckleton, R.P., A.R. Watkinson, D.J. Webb and T.H. Thomas .(1999). Yield of sugar beet in relation to weather and nutrients. Agric. Forest Meteorology, 93: 39-51.

Heitholt, J.J. and G.F. Sassenrath .(2010). InterPlant Competition: Growth responses to plant density and row spacing physiology of cotton, pp: 179-186

Hozayn, M., M.M. Tawfik, H.M. Abd El-Ghany and A.M Korayem (2013). Effect of plant density on yield and sugar quality characteristics of sugar beet. J. of Applied Sci. Res., 9(1): 1004-1009.

Hozayn, M., A. A. Abd El-Monem and A. A. Bakery (2013). Screening of some exotic sugar beet cultivars grown under newly reclaimed sandy soil for yield and sugar quality traits. J. Appl. Sci. Res., 9(3):2213-2222.

Ismail, A.M.A. and S.M. Allam .(2007). Yield and technological traits of sugar beet as affected by planting density, phosphorus and potassium fertilization. The $3^{\text {rd }}$ Conf. Sustain. Agric. Develop., Fac. Agric., Fayoum Univ., 12-14 Nov., pp.15-28. 
Ismail, A.M.A., A.H.S. Al-Labbody and N.M.S. Shalaby.(2006). Variability and traits relationship in nine sugar beet varieties under three sowing dates. Egypt. J. Plant Breed., 10 (1): 387-406.

Jackson, M.L. (1967). Soil chemical analysis, prentice-hall India private limited, New York.

Kaffka, S. and K. Hembree .(2004). The effects of saline soil, irrigation, and seed treatment on sugar beet stand establishment. J. Sugar Beet Res., 41: 61-72.

Lauer, J. G. (1995). Plant density and nitrogen rate effects on sugar beet yield and quality early in harvest. Agron. J., 87:586-591.

Le Docte, A. (1927) Commercial determination of sugar beet root using the Sacks Le-Docte Process. Int. Sugar J., 29: 488-492.

Maas, E.V (1986). Salt tolerance of plants. Appi. Agric. Res. 1(1): 12-26.

Marschner, H. (1995). Mineral nutrition of higher plants, $2^{\text {nd }}$ ed. London, Academic Press. UK:

Merwad, A.M.A. (2015). Effect of potassium fertilization and salicylic acid on yield, quality and nutrient uptake of sugar beet (Beta vulgaris ,L.) grown in saline soil. Malaysian J. Soil Sci.,19:95-105.

Minx, L. (1993). The effect of row spacing on the productive utilization of distances between plants by the sugar beet stand. Rostlinna vyroba, 39 (b):531-541.

Nafei. A.I.; A.M.H. Osman and Maha M. El-Zeny (2010). Effect of plant densities and potassium fertilization rates on yield and quality of sugar beet crop (Beta vulgaris L.) in sandy reclaimed soils.. J. of Plant Production, Vol. 1(2):229-237.

Sadughi, M., H. Sharifan and M. Pessarakli .(2015). Effect of caspian sea water on sugar beet seed germination. J. Plant Nutr., 38:1685-1693.
Safina, S. A., M. A. Hassanin, EL-Met. A. ELMetwally and N.R. Elsherbini .(2012). Sowing date and plant density influences on yield and quality of some sugar beet varieties grown in sandy soils under drip irrigation system. J. Egypt. Acad. Soc. Environ. Develop., 13 (2):7385.

Shalaby, N.M.E., A.M.H. Osman and A.H.S. A. AL-Labbody .(2011). Relative performance of sugar beet varieties under three plant densities in newly reclaimed soil. Egypt. J. Agric. Res., 89 (1):291-299.

Snedecor, G.W. and W. G. Cochran (1981). Statistical methods $7^{\text {th }}$ Ed Iowa State Univ. Press, Ames, Iowa, USA.

Thalooth, A.T., M. M. Tawfik, Elham A. Badre and Magda H. Mohamed .(2019). Yield and quality response of some sugar beet (Beta vulgarisL.) varieties to humic acid and yeast application in newly reclaimed soil. Middle East J. Agric. Res., 8(1):56-65.

Tognetti, R., M. Palladino, A. Minnocci, S. Delfine, and A. Alvino (2003). The response of sugar beet to drip and low-pres-sure sprinkler irrigation in southern Italy. Agricultural Water Management 60:135-155. doi:10.1016/S03783774(02) 00167-1.

Waller, R.A. and D.B. Duncan (1969). A bays rule for symmetric multiple comparison problem. Amer. Stat. Assoc. J., 1485-1503.

Yan, L., F. Tingting Fu, S. Sui, D. Tonglou, D. Xihua, S. Jie and W. Baoshan (2014). Response of sugar beet to salinity during the stages of seedling emergence and plant growth. Appl. Mech. and Materials. Vols (522-524):11021108 .

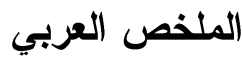

\section{استجابة بعض أصناف بنجر السكر المنزرعة تحت ظروف الأراضي الملحية والكثافات النباتية المختلفة}

$$
\begin{aligned}
& \text { كرم عبدالصادق جوده عبدالسلام، باسم صبحي إبراهيم مخلوف، علي محمد علوان فاضل، أميرة عيد الثريف }
\end{aligned}
$$

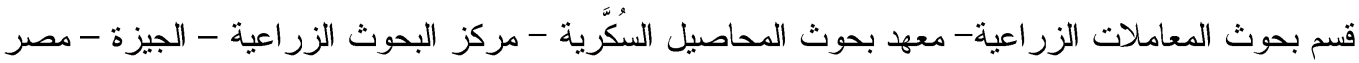

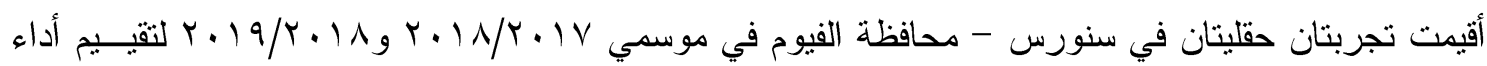

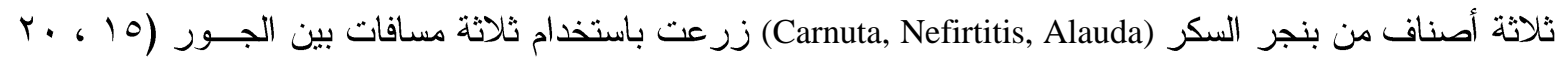

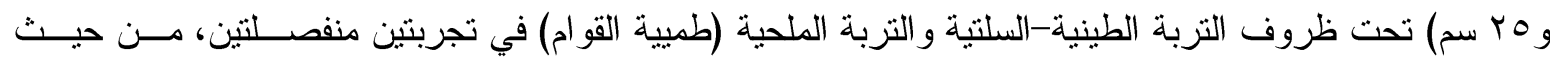

$$
\begin{aligned}
& \text { المحصول و الجودة. تحت كل نوع تربة استخدم تصميم القطع المنشقة مرة واحدة في ثلاث مكررات، حيث وضعت }
\end{aligned}
$$


المسافات بين الجور في القطع الرئيسية، بينما وزعت الأصناف بشكل عشوائي في القطع الثقية، وتم عمل التحليـلـل

$$
\text { التجميعي لنوعي التربة في كل موسم علي حدة. }
$$

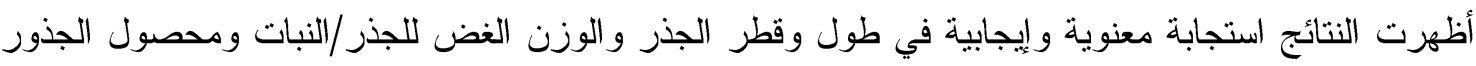

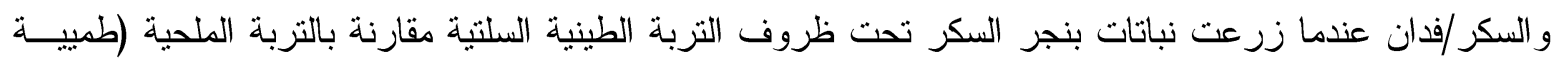

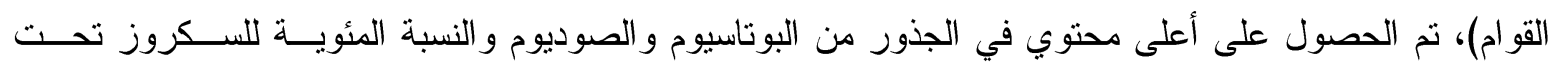
ظروف التربة المالحة، وذلك في كلا الموسمين. ازداد الطول و القطر و الوزن الغض للجذر/نبات ومحصول السكر/فدان زيادة تدريجية ومعنوية بزيادة المسافات

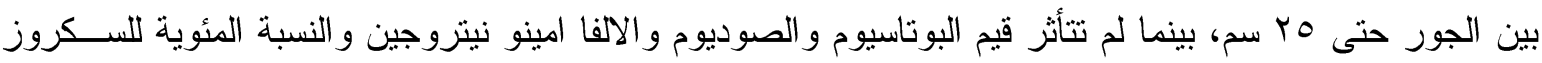
و النقاوة ، وذللك في كلا الموسمين. اختلفت الأصناف المختبرة معنويا في قطر الجذر و الوزن الغض/النبات في كلا الموسمين، وفي طول الجذر في الموسم الأول فقط، ومحصول الجذور/فدان في الموسم الثاني. حقق الصنف Carnuta اعلي وزن للجذور متفوقا على

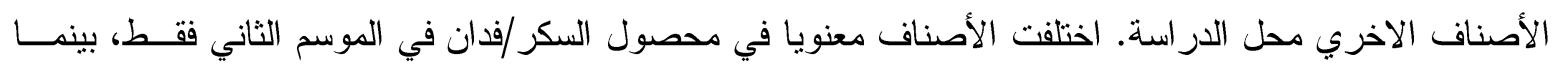

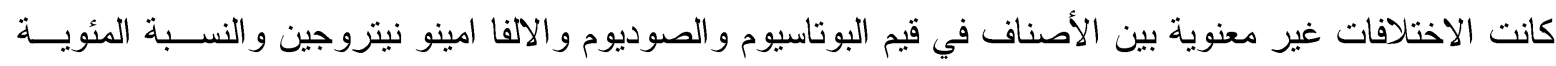

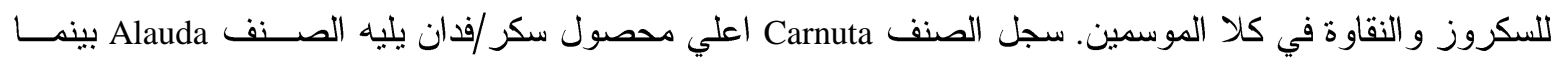
سجل الصنف Nefirtitis اقل القيم في الموسم الثاني. أظهر التفاعل بين نوعي التربة و المسافة بين الجور تأثيرات معنوية في قطر الجذر في كلا الموسمين وكـذلك محصول السكر/فدان في الموسم الثاني فقط.

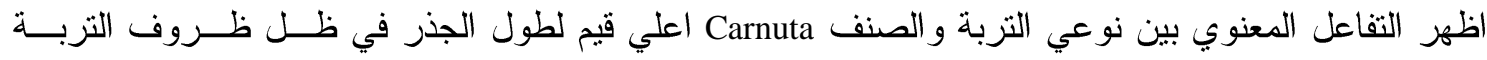
الطينية، بالمقارنة مع الأصناف الأخرى المختبرة في الموسم الأول.

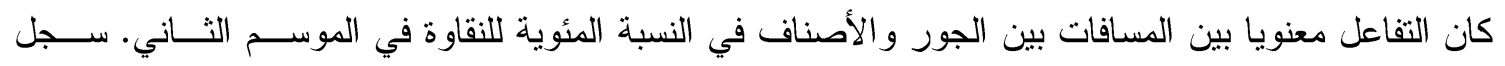

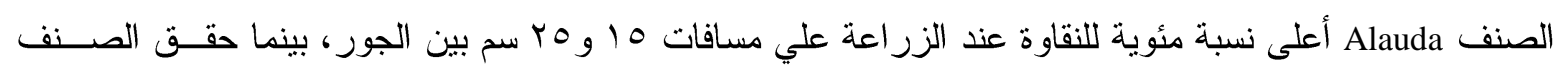

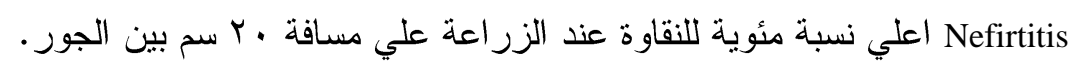

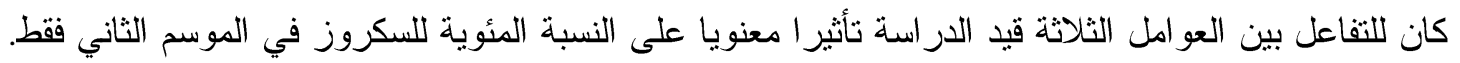

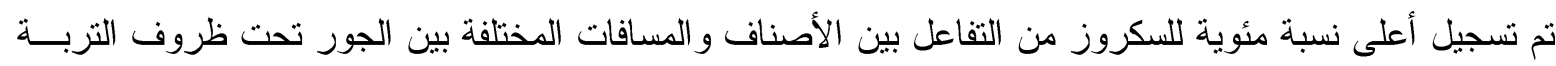
الملحية مقارنة بظروف التربة الطينية. استتادا إلى النتائج التي تم الحصول عليها، تبين أنه يمكن التوصية بزر اعة صنف بنجر السكر Carnuta علــى

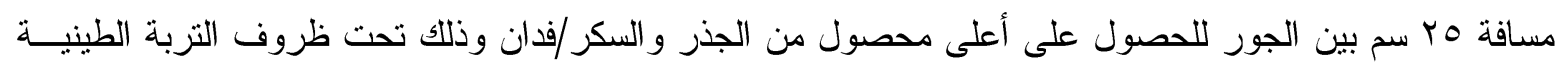
السلتية أو الملحية التربة الملحية (طيية القوام). 